\title{
Language Identity in Maritime Defense Diplomacy
}

\author{
Fransisca Dewi Ratih* \\ Graduate Student of the Linguistic Department \\ Universitas Indonesia \\ Depok, Indonesia \\ Im_ekadewi@yahoo.com
}

\author{
Sisilia Setiawati Halimi \\ Lecturer of the Linguistic Department \\ Universitas Indonesia \\ Depok, Indonesia \\ sshalimi@gmail.com
}

\begin{abstract}
There is no doubt that language and identity are interrelated and influencing each other. One function of language is as a nation's cultural identity. Politeness in language is a form of cultural identity, and culture can be integrated into English teaching to improve communication skills. This is fundamental in carrying out maritime defense diplomacy tasks. Foreign language training programs are vehicles that have the potential for bolstering a country's identity. Therefore, this study aims to examine the compatibility between the syllabus applicable in an English language training program at Indonesian Navy's language institute and the required language competency related to maritime defense diplomacy activities. This research is a qualitative, descriptive, and interpretive study. Questionnaires and interviews were used in this study, and document examinations were carried out to identify the needs of the 33 alumni of the training program. It was found that listening and speaking skills were very important for carrying out the respondents' duties as Navy officers. In addition, the respondents agreed that topics related to cultural identity could increase their motivation; and therefore, they were considered effective in improving their English language proficiency. However, the majority of the respondents said the benefit of the course that they had participated in was only to prepare them to take the TOEFL test, and most of the respondents agreed that the course had no direct correlation with the English language competency which they need to carry out their duties. It is concluded that the current syllabus is not compatible with the needs of English language competency required by those Navy officers for carrying out their duties. Based on these findings, it is necessary to improve the syllabus by aligning it with organizational goals and to make sure that the people who have the responsibilities of communicating our national identity are really equipped with the language skills needed.
\end{abstract}

Keywords-ESP, identity, maritime defense diplomacy, needs analysis, course design

\section{INTRODUCTION}

Bertrand (2003, as quoted in Goebel, 2010) claims that Indonesia is renowned as one of the nations with a huge variety of cultures, languages, and religions. Such diversity has attracted the attention of many scholars, especially experts in politics, history, anthropology, and culture (Goebel, 2010). He also said that one of the defining features of Indonesia is politeness in language use. Based on these researchers' opinions, we can say that Indonesians are really known for their linguistic politeness. Goebel (2010) provides an example of the Javanese language that has a different level of politeness in its use. By understanding this view, it can be said that Indonesia as a nation has a cultural identity of politeness in language. Politeness in conversation is conducted through a speech "Act".

"Acts" conducted by speakers will intrinsically threaten self-esteem/facial expressions, face, of the speech partners termed Face Threatening Acts (FTAs). When a speaker has to perform an FTA, he/she will minimize the threat of that facial expression by adopting some appropriate communication strategies. Five strategies in conversation proposed by Brown \& Levinson (1987) are record)

1) Very poor FTAs, without empathy (bald on

2) Offsetting the positive face (positive politeness)

3) Offsetting the negative face (negative politeness)

4) Performing an implied FTA (imposing indirectly)

5) Not performing FTA.

The greater the politeness degree of the 5 strategies above, the higher the politeness level is. Point 1 has the worst degree of politeness and point 5 has the best politeness degree. If the FTA is more threatening, the speaker will increasingly choose a strategy that has a high degree of politeness. Goebel (2010) states that Indonesia's national culture is well known for its politeness in language.

Cingolani (2014) also says that language and identity are one indivisible unity which are bound by and influence each other. He also thinks that language is a marker of human identity and culture. When we hear somebody talking, we can instantly guess his or her sex, education level, age, profession, and place of origin (Spolsky, 1999). Based on Spolsky's opinion above (1999), we can say that a nation's language identity can be identified and recognized through their communication competency in the diplomatic arena. According to Badri (2008 in Siswanto, 2015), diplomacy is an art of managing international relationships through various means, one of which is negotiation. Meanwhile, according to Sudirman and Nugraha (2016), maritime defense diplomacy is a term which covers various activities carried out at the sea or within the maritime borders of the Republic of Indonesia, and this is one of the principal responsibilities of the Indonesian Navy. However, there are several problems in the implementation of diplomatic activities, such as low quality human resources, especially in terms of foreign language proficiency. According to Spolsky (1999), language proficiency and competency are stepping stones towards the international recognition of a nation's identity. Meanwhile, Faqih (2014) asserts that the improvement of human resources and education institutions is an urgent thing to do. In relation to this need, we can say that foreign language training programs are a potential means for bolstering a nation's identity. Because of this, we are interested in evaluating the 
syllabus of an English training program at the Indonesian Navy's language institute by comparing it with a needs analysis which was carried out according to the principles of English for specific purposes (ESP), namely by comparing it with the communication skills required in the area of maritime defense diplomacy. The question to be answered in this research is "to what extent the current syllabus is compatible with the needs analysis of the communication competency in the area of maritime defense diplomacy?"

An important element in ESP is needs analysis which is carried out to examine learners' needs when learning a language (Basturkemen, 2010). According to Dudley-Evans and St. John (1998) ESP focuses on the practical results of English language usages and is intended to achieve specific communication competency suitable for a particular professional area.

Several researchers have carried out studies related to our topic, such as Safitri (2016) who focused on evaluation of the syllabus and course book which were used in an English training program at the Indonesian Police's Language School in Jakarta, Indonesia; Ulum (2017) who conducted needs analysis in order to find out the extent of their needs of English at their workplace in Antalya, Turkey; and Alfarisi (2018) who carried out a study at the Police's language school in East Jakarta, Indonesia in order to examine police officers' needs of French.

By studying previous literature, we sought to carry out needs analysis in relation to English communication competency in maritime defense diplomacy. The purpose of this is to ensure that Indonesian people's exceptional characteristic as polite speakers of their native language can also be reflected in their use of English. Besides that, we also think that, even though maritime defense diplomacy has been the topic of many studies, there has not been any research on the role of English competency in strengthening a nation's identity. Because of that, we chose this topic as the main focus of this research.

\section{RESEARCH METHODS}

\section{A. Research Context}

This research examines the need of English competency in the context of Indonesian maritime diplomacy. This research selected an English training program at the Indonesian Navy's language institute as its main object of investigation. The program in question was named Kursus Intensif Bahasa Inggris Siap (KIBI Siap). KIBI Siap is an English training program which was intended to prepare its participants for accomplishing their obligation to pursue higher education and for carrying out their duties abroad.

\section{B. Data Collection Instruments}

Data triangulation was carried out in this research in order to obtain a clearer picture of the need of English competency in the context of Indonesian maritime defense diplomacy. Data were collected by means of a questionnaire and semi-structured interview. The questionnaire was divided into two parts; the first part was intended to analyze the language learning situation, while the second part was intended to analyze the current situation needs. The first part consisted of five questions about learners' perception of
English learning. The second part consisted of questions for analyzing learners' needs in relation to English communication competency in the context of maritime defense diplomacy. This part consisted of three groups of questions with 26 questions in total. Questions in the first group were intended to identify learners' language proficiency level; questions in the second group were intended to identify the English skills required for maritime defense diplomacy; and questions in the third group were intended to evaluate the compatibility between learners' needs and the current syllabus. The last part of the identification of learners' needs in terms of language use and learning was the target situation needs analysis. At this stage, we carried out a semi-structured interview with ten research subjects who had been actively involved in activities related to maritime defense diplomacy. $30 \%$ of the questionnaire respondents were selected for participating in this interview, which is the minimum percentage of samples selected for such purpose (Sudijono, 2012). This interview was intended to gain further insight into the target situation needs, so that we could interpret the data in a more accurate way.

\section{Research Subjects}

The subjects of this research were 33 alumni of KIBI Siap, batch 2017-2019, who consisted of both civil servants and military officers. We, the researchers, were parties external to this language training program.

This program is conducted to prepare the participants for taking Test of English as a Foreign Language, InternetBased Test (TOEFL iBT). Participants of KIBI Siap who manage to obtain high scores during the training program will be recommended to take TOEFL iBT at an accredited test center. The scores obtained from the test center will serve as a requirement for pursuing higher education abroad and for involving them in various activities related to maritime defense diplomacy.

\section{Data Analysis}

This research applied the mixed method, namely the combination of both quantitative and qualitative analyses. Questionnaire results were statistically calculated by looking for the highest frequency of respondents' answers, as proposed by Ulum (2017). In order to describe these quantitative data, a descriptive analysis was carried out, so that the data could be understood and interpreted in a correct way. Interview recordings were transcribed using the writing format as proposed by Hammersley (1994). We assigned a code to each transcription data which were derived from the interview, and then we looked for any key category which could represent all categories of the transcription data. After that, the results of our interview data analysis were described.

According to our questionnaire data analysis results in the form of average scores, we can see respondents' level of English proficiency (see Table 1). These average scores were adapted from the frequency calculation technique as applied by Ulum (2017). Average scores were calculated directly from the frequency which had been obtained using Microsoft Excel. 
TABLE 1. AVERAGE SCORES OF RESPONDENTS' LANGUAGE PROFICIENCY

\begin{tabular}{|c|r|r|r|r|r|r|}
\hline Skill & $\begin{array}{c}\text { Very } \\
\text { bad }\end{array}$ & Bad & Fair & Good & $\begin{array}{c}\text { Very } \\
\text { good }\end{array}$ & $\begin{array}{c}\text { Averag } \\
\text { e } \\
\text { scores }\end{array}$ \\
\hline Listening & 0 & 0 & $\mathbf{1 6}$ & $\mathbf{1 6}$ & 1 & 3.55 \\
\hline Speaking & 0 & 1 & $\mathbf{1 9}$ & 13 & 0 & 3.36 \\
\hline Reading & 0 & 0 & $\mathbf{1 7}$ & 15 & 1 & 3.52 \\
\hline Writing & 1 & 0 & $\mathbf{2 4}$ & 8 & 0 & 3.18 \\
\hline
\end{tabular}

Average scores were used to rate the respondents' general proficiency per skill. The higher the average score, the higher the average number of respondents who answered "good" and "very good".

By analyzing the results of our questionnaire data analysis, we attempted to measure the compatibility between the communicative functions required in maritime defense diplomacy activities and the current training program syllabus. Table 2 below presents which functions fall into any of those five categories. The results of this questionnaire data analysis were then triangulated by using the results of our interview data analysis (see Table 2).

TABLE 2. COMMUNICATIVE FUNCTIONS REQUIRED FOR PERFORMING TASKS RELATED TO MARITIME DEFENSE DIPLOMACY

\begin{tabular}{|c|c|c|}
\hline \multirow{2}{*}{$\begin{array}{c}\text { Communicative } \\
\text { function from the } \\
\text { questionnaire }(n=33)\end{array}$} & \multicolumn{2}{|c|}{ Interview result $(n=10)$} \\
\hline & $\begin{array}{l}\text { Communicative } \\
\text { function }\end{array}$ & Percentage \\
\hline \multicolumn{3}{|l|}{$\begin{array}{l}\text { Very important } \\
(26.9 \%)\end{array}$} \\
\hline Giving reasons & $\begin{array}{l}\text { Arguing (offering } \\
\text { or asking for } \\
\text { explanations) }\end{array}$ & $100 \%$ \\
\hline \multirow{4}{*}{$\begin{array}{l}\text { Giving or receiving } \\
\text { orders, offering or } \\
\text { accepting suggestions, } \\
\text { expressing or accepting } \\
\text { apology, expressing } \\
\text { gratitude, expressing } \\
\text { compliments }\end{array}$} & $\begin{array}{l}\text { Understanding } \\
\text { conversations }\end{array}$ & $90 \%$ \\
\hline & $\begin{array}{l}\text { Drawing } \\
\text { conclusions from } \\
\text { a conversation }\end{array}$ & $80 \%$ \\
\hline & $\begin{array}{l}\text { Offering } \\
\text { accepting } \\
\text { suggestions }\end{array}$ & $70 \%$ \\
\hline & $\begin{array}{l}\text { Expressing } \\
\text { opinions or ideas }\end{array}$ & $70 \%$ \\
\hline $\begin{array}{l}\text { Expressing } \\
\text { disagreement }\end{array}$ & $\begin{array}{l}\text { Making } \\
\text { objections }\end{array}$ & $40 \%$ \\
\hline \multicolumn{3}{|l|}{ Important $(19.2 \%)$} \\
\hline \multirow{3}{*}{$\begin{array}{l}\text { Offering or accepting } \\
\text { advice, expressing } \\
\text { disagreement, offering } \\
\text { or accepting criticism, } \\
\text { making requests, } \\
\text { reminding other people }\end{array}$} & $\begin{array}{l}\text { Understanding } \\
\text { conversations }\end{array}$ & $90 \%$ \\
\hline & $\begin{array}{l}\text { Drawing } \\
\text { conclusions from } \\
\text { a conversation }\end{array}$ & $80 \%$ \\
\hline & $\begin{array}{l}\text { Expressing } \\
\text { opinions or ideas }\end{array}$ & $70 \%$ \\
\hline \multicolumn{3}{|l|}{ Fair (7.7\%) } \\
\hline $\begin{array}{l}\text { Making or accepting } \\
\text { complaints and }\end{array}$ & $\begin{array}{l}\text { Understanding } \\
\text { conversations }\end{array}$ & $90 \%$ \\
\hline
\end{tabular}

\begin{tabular}{|c|c|c|}
\hline \multirow[t]{2}{*}{$\begin{array}{l}\text { reprimands, accepting } \\
\text { offers }\end{array}$} & $\begin{array}{l}\text { Drawing } \\
\text { conclusions from } \\
\text { a conversation }\end{array}$ & $80 \%$ \\
\hline & $\begin{array}{l}\text { Expressing } \\
\text { opinions or ideas }\end{array}$ & $70 \%$ \\
\hline \multicolumn{3}{|l|}{ Unimportant (11.5\%) } \\
\hline \multirow{2}{*}{$\begin{array}{l}\text { Issuing or accepting } \\
\text { warnings, expressing or } \\
\text { receiving reprimands, } \\
\text { making or accepting } \\
\text { promises } \\
\end{array}$} & $\begin{array}{l}\text { Understanding } \\
\text { conversations }\end{array}$ & $90 \%$ \\
\hline & $\begin{array}{l}\text { Drawing } \\
\text { conclusions from } \\
\text { a conversation } \\
\end{array}$ & $80 \%$ \\
\hline \multicolumn{3}{|l|}{$\begin{array}{l}\text { Very unimportant } \\
(34.7 \%)\end{array}$} \\
\hline \multirow{2}{*}{$\begin{array}{l}\text { Making or receiving } \\
\text { threats, making or } \\
\text { receiving accusations, } \\
\text { insulting }\end{array}$} & $\begin{array}{l}\text { Understanding } \\
\text { conversations }\end{array}$ & $90 \%$ \\
\hline & $\begin{array}{l}\text { Drawing } \\
\text { conclusions from } \\
\text { a conversation } \\
\end{array}$ & $80 \%$ \\
\hline $\begin{array}{l}\text { Conveying impressions, } \\
\text { giving rewards, } \\
\text { persuading }\end{array}$ & $\begin{array}{l}\text { Expressing } \\
\text { opinions or ideas }\end{array}$ & $70 \%$ \\
\hline Daily conversations & $\begin{array}{l}\text { Daily } \\
\text { conversations }\end{array}$ & $60 \%$ \\
\hline
\end{tabular}

According to the table, all communicative functions listed above are strongly associated with conversations involving two or more people. In other words, the required communicative functions are the ones related to interactionbuilding skills. According to Cingolani (2014), all human beings are actively building their own identity, both as an individual and as a member of a group, through interactions in order to gain social recognition.

Aside from that, the processed data derived from the interviews show $90 \%$ of the respondents felt more comfortable with the implementation of teaching materials that integrate cultural identity in learning the 4 English language skills. One of them is Capt. IH, who felt more comfortable discussing legends or wayang (shadow puppet) stories and relating them to current conditions in learning speaking or writing skills.

(Interview of Capt. IH)

4 R : emm, ide bagus. Saya suka cerita Candrabirawa.

5 P: Candrabirawa, apa itu?

$6 \mathrm{R}$ : sejenis ilmu dalam dunia pewayangan.

Kpt IH (2019, 31 Agustus) - a semi-structured interview.

Translation of the interview with Capt. IH:

4. R: emm.. a great idea, I like the story of

Candrabirawa

5. P: Candrabirawa, what's that?

6. R: a kind of science in the world of puppets.

The respondents' choice on the use of teaching materials that integrate cultural identity in learning a foreign languages is in line with the results of Menggo's research (2019), which 
indicate that the use of local cultural identity can improve speaking skills.

Meanwhile, $80 \%$ of the respondents chose level 4 of Brown \& Levinson (1987) politeness strategies in conversation, namely implied FTA (quipping indirectly) and level 5, not performing any FTAs. Only $20 \%$ of the respondents chose level 3 of the politeness strategies in conversation, i.e. offsetting the negative face or negative politeness.

The politeness strategies in conversation chosen by the majority of respondents validate the opinion of Goebel (2010) who claims that Indonesia is known for having a cultural identity in the politeness of language use. He considers politeness in conversation as a form of cultural identity.

\section{RESULTS AND DISCUSSION}

\section{A. Results related to communicative functions for supporting duty performance}

All of the communication functions are strongly related to interactions in a conversation. Therefore, these communication functions are closely related to the mastery of speaking skills. This is very consistent with the results of the research by Ulum (2017) and Alfarisi (2018). Interactions in a conversation involve identity as a social element.

A sociocultural perspective views identity as a social factor that can be developed during an interaction with other people or other groups and can be influenced by the surrounding conditions or context. This may determine whether the identity can be recognized during a conversation (Cingolani, 2014). Skills in using linguistic resources during communication and in interpreting other people's language use can help someone to build his or her own personality, to shape what he or she thinks about other people, and to identify what other people think about him or her. In other words, language is a potential tool for shaping an identity (Beacco in Cingolani, 2014). By taking account of these ideas, we believe that an individual must have sound English proficiency and competency during interactions, so that his or her identity may gain social recognition from other people.

\section{B. Results of the evaluation of English competency in KIBI Siap training program}

Based on our questionnaire results, we found that almost all respondents had received learning materials which were provided by the English training program. However, based on the semi-structured interview results, the respondents said that, even though all of the provided materials had been taught, there was not enough time to do exercises, especially those related to the four main language skills. Because of this, almost all respondents felt that they did not make much progress after finishing the language training program

The respondents felt that in listening they were "not proficient" in five sub-skills. The respondents also felt that the speaking skill is their weakest point. Speaking skills deserves more attention because the respondents felt that they still had poor speaking skills in spite of the training program.

Different from the previous two main skills, reading skills show the highest rate of proficiency among respondents. In spite of the respondents' relatively high reading proficiency, there are still some subskills which need to be improved.

Next, there are nine writing sub-skills which the respondents did not feel proficient in. Writing in general is one of the skills which most respondents feel they need to improve.

Besides that, other results from the interviews show that most respondents felt comfortable with the integration of teaching materials with local cultural identity. It is believed that the integration of cultural identity into language teaching can improve communication competence. Aspects related to cultural identity such as legends, wayang stories, meaning of ceremonies/customs, or other local customs can be used as topics in teaching English.

Most of them also implemented a conversation strategy with a high level of politeness, namely strategies level 4 and 5 based on the application of Brown \& Levinson's politeness strategies in conversation (1996). This finding shows the cultural characteristic/identity of the Indonesian people.

According to our examination of English competency needs, speaking skills, supported by listening skills, are greatly needed by those who have to carry out their professional duties. Meanwhile, according to the results of our semi-structured interview, most respondents felt that writing skills are only absolutely needed for carrying out diplomatic duties which are related to higher education.

According to Falahi (as quoted in Rachmawati, 2011) the diplomatic missions themselves are part of the country's or nation's effort to build a strong identity and bolster its positive image. In consideration of this view, it is imperative that the four main English skills be mastered by people who work in the area of maritime defense diplomacy. More specifically, this research also found that there is an immediate need to improve three main skills, namely writing, speaking, and listening (in descending order) because many respondents felt that they were not proficient in those skills (69\% for writing, $60 \%$ for speaking, and $26 \%$ for listening).

\section{CONCLUSION}

Everyone who is involved in maritime defense diplomacy must take account of English communicative functions which fall into the categories of "most important" and "important" when carrying out their duties. Learners have to be proficient in the skills which can support the performance of their duties. Findings related to these communicative functions must be incorporated into English lessons, according to the language skills that are required.

All communication functions needed in maritime defense diplomacy activities are related to the mastery of English language skills for conducting a negotiation. This validates the view of Badri (2008 in Siswanto, 2015) which states that diplomacy is the art of managing international 
relations, and one way of doing so is through negotiation. This is also in line with the research findings of Ulum (2017) and Alfarisi (2018) which indicate that speaking skills are the most required skills supported by listening skills.

The integration of topics related to local culture has been chosen to teach cultural identity in this KIBI Siap program. Topics that are familiar to students can increase motivation and vocabulary (Yuli, 2019) so that the required communication competencies needed to carry out maritime diplomacy can be achieved.

Another finding related to the politeness strategies show that the respondents have a high degree of politeness. This shows the cultural identity of Indonesian speakers in general. Both Goebel (2010) and Cingolani (2014) consider this politeness as a form of cultural identities. With this, we can conclude that what needs to be improved is the respondents' English proficiency so that they will have no difficulties in using the politeness strategies in the maritime defence diplomacy.

According to the results of our examination of the compatibility between the current syllabus and our needs analysis results, we found that almost all research respondents felt that this language training program did not have a direct correlation with the English skills that they need to carry out their professional duties. The respondents felt that there was an incompatibility between the materials provided in the program and the communication competency relevant to the area of maritime defense diplomacy. Because of that, the current syllabus has to be improved, so that it may be more compatible with the communication competency and skills required for carrying out duties related to maritime defense diplomacy.

The following are some suggestions for the development of research on the English syllabus for the purpose of tasks/activities in maritime defense diplomacy. First, including the elements and types of cultural identity in detail in the questionnaire are considered important before designing a syllabus. Secondly, questions related the five politeness strategies in conversation along with several examples are also important to be included in the questionnaire. Third, the selected interview respondents should be diverse by taking into account various ethnicities or cultural origins. By paying attention to the suggestions above, future research is expected to be more detailed in obtaining the aspects related to cultural identity that can be used as tools in teaching English.

\section{ACKNOWLEDGMENT}

This work has been supported by the Directorate of Research and Engagement, Universitas Indonesia.

\section{REFERENCES}

Alfarisi, S. A. (2019). French for police officers at police language school Jakarta: A need analysis. Advances in social science, education and humanities research, 257. 86-89.

Brown, H. D. (2004). Language assessment: Principle and classroom practices. New York: Pearson Education.

Basturkemen, H. (2010). Development courses in English for specific purposes. New York, USA: Palgrave Macmillan.

Cingolani, C. (2014). Language and identity: Identity planning and language policies in Canada. University of Belgrano. Unpublished undergraduate thesis.

Evans, D. \& St. John, M. J. (1998). Developments in English for specific purposes. United Kingdom: Cambridge University Press.

Faqih, M. (2014, February 26). Ini cara TNI AL untuk jadi "world class navy". Republika. Accessed on 18 April 2019 from http://www.republika.co.id/berita/nasional.

Goebel, Z. (2010). Language, immigration, and identity. New York, USA: Cambridge University Press.

Hammersley, M. (1994). Etnografi ruang kelas. Semarang: IKIP Semarang Press.

Menggo, S. (2017). Budaya lonto leok dalam kemampuan berbicara. International conference on language, literature and teaching, , 1 (2017), 765-772

Rachmawati, I. (2011). Indonesia public diplomacy: Perserving state existence through sharing of identities to gain mutual understanding. Global and strategies, 1(11), 55-71.

Siswanto, L., A. (Mei, 2015). Diplomasi Indonesia di laut Cina Selatan. Cakrawala, 425, 38-41.

Sudirman \& Nugraha (April, 2016). Latihan bersama dalam kemitraan pasifik. Patriot, 44, 12-14.

Spolsky, B. (1999). Second-language learning. In J. Fishman (Ed). Handbook of language and ethnic identity (pp. 181-192). Oxford: Oxford University Press

Safitri, D. (2016). Evaluation of ESP Syllabus and the ESP Course Book Used at Indonesian Police Language (SEBASA) Jakarta. Unpublished Master's thesis. UNIKA Atma Jaya, Jakarta, Indonesia.

Sudijono, A. (2012). Pengantar statistik pendidikan. Jakarta: Rajawali Press.

Ulum, O.G. (2017). ESP needs analysis of public order police officers. International Online Journal of Education and Teaching (IOJET) 2017, 4(1), 19-30.

Yuli, E., M. (2019). Pengaruh familiaritas topik terhadap performa menulis siswa sekolah menengah atas kelas XI. Unpublished Master's thesis. Program Magister Ilmu Linguistik, Faculty of Humanities, Universitas Indonesia, Jakarta, Indonesia. 